\title{
Is It Crucial to Use Information-Based Theory in Explaining Attitude towards Change?
}

\author{
Tulus Winarsunu \\ Universitas Muhammadiyah Malang \\ tuluswinar@gmail.com
}

\begin{abstract}
The purpose of this article is to describe the various theories used in research on attitudes to change. Theoretical framework that has been used could be grouped into three perspectives, which are based on social influence, individual differences, and information. Based on literature review in that three perspectives, there is a theoretical gap in the perspective of information, however it is not in the first two. Accordingly, authors recommend the use of information perspectives, particularly focus on theory of information framing when to do attitude research. This needs to be done not only to clarify the effect of information factors on attitudes towards change, but also to develop research based on information theory in the future.
\end{abstract}

Keywords: attitude towards change; social influence-based theory; individual difference-based theory; information-based theory.

\section{INTRODUCTION}

In generalorganization would continually design and execute several change programs (Fugate, Prussia, \&Kinicki, 2012; Shin, 2013). It is implemented in order to adapt with the dynamic environment (Liu \&Perrewe, 2005; Dam, Oreg, \&Schyns, 2008). Nevertheless, not all change programs could be implemented as planned (Knippenberg, Martin, \& Tyler, 2006; Herzig \& Jimmieson, 2006; Kuntz \& Gomes, 2012). Previous studies found that the success of any change programs is influenced by attitudes towards the changes (Lines, 2005; Herold, Fedor, \& Caldwell, 2007; Kuntz \& Gomes, 2012; Oreg, Vakola, $\&$ Armenakis, 2011). Positive attitudes increase such a success (Wharton \& Brunetto, 2007; Hornung \& Rousseau, 2007) and negative attitudes cause failures in the implementation of change programs (Neiva, Ros, \& Tores da Paz, 2005; Danisman, 2010). To make such change programs able to be implemented as planned, organizations should grow up some positive attitudes towards changes among their members (Oreg, 2003; Jones, Jimmieson, \& Griffiths, 2008).

There are some theories that may be used to explain the antecedent of attitudes towards change, namely social influence-based theory, individual differencebased theory, and information-based theory. First, the social influence-based theory includes social exchange theory (Emerson, 1976), social identity theory(Tajfel, 1982), and social information processing approach(Salancik \& Pfeffer, 1978). According to the social exchange theory, attitude is considered as the function of reciprocal social relationship (Emerson, 1976; Cropanzano \& Mitchell, 2005) generating interdependent responsibility and characteristics among those in a social relation (Cropanzano \&
Mitchell, 2005). In some researches, it is revealed that employees' positive attitudes towards any changes is response to some good treatment they get from their leader (Wharton \& Brunetto, 2007; Dam, Oreg, \& Schyns, 2008). The social identity theory, explains how one's conception is influenced by his/her individual member status in his/her social group (Tajfel, 1982). An individual in the high level of organizational identification significantly shows a more positive attitude towards organizational changes (Knippenberg, Martin, \& Tyler, 2006). The social information processing approach,explains that an attitude is adaptively formed in accordance with any information one gets from others (Salancik \& Pfeffer, 1978). In a research it is found that any comment or opinion from a credible source may give a very strong effect on employees' attitudes towards changes (Ellis, 1992).

Second, an individual difference-based theory; covers the self regulation theory(Bandura, 1977), the traits personality perspective (Tsaousis, 1999), and the theory of personal values(Schwartz, 1992). This group argues that an attitude formed is potentially from oneself (Oreg, 2006). The self regulation theory suggests that an individual has different ability in reaching a set goal (Bandura, 1991, 1999). An employee who thinks that he may be able to face some changes possesses more capability in setting a goal and shows more serious efforts in succeeding organizational change programs (Kuntz \& Gomes, 2012). The traits personality perspective explains that internally an individual possesses some tendency to be stable to refuse or to accept any organizational change programs (Oreg, 2003). Vakola, Tsaousis and Nikolaou (2004) using the five factor model, reveal that traits are related to positive attitudes towards change namely extraversion, agreeableness, 
conscientiousness, and openness to experience; but are negatively correlated with neuroticism. The theory of personal values explains that attitudes are influenced by personal values (Sverdlik \& Oreg, 2009). Personal values are standards serving as a social justification about certain attitudes(Roccas, Sagiv, Schwartz, \& Knafo, 2002). In a research, an openness to change values and conservation values respectively are positively and negatively correlated with one's will to support organizational changes(Kwang, Ang, Ooi, \& Leng, 2005)

Third, the information-based theory; covers the uncertainty reduction theory (Berger \& Calabrese, 1975), information processing approach (Kuvaas, 2002), behavioral decision making approach (Kuvaas, 2002), and schematic approach (Fiske \& Tylor, 1984). The uncertainty reduction theory regards that an individual always wants to reduce any uncertain situation by seeking information available in one's environment (Berger \& Calabrese, 1975). The more information, the more possibilities to reduce uncertainty and ambiguity will be; then this will influence one's acceptance to organizational changes ( (Ellis, 1992; Dam, Oreg, \& Schyns, 2008; Wanberg \& Banas, 2000). According to the information processing approach, the more information, the more raw materials are used to interpret and to understand any facts in an environment (Kuvaas, 2002). Any addition of the amount of information also influences some knowledge and also changes an individual's perception (Kuvaas, 2002).

In contrast with the two explanations above, according to the behavioral decision making approach, the amount of information will not reduce any uncertainty and ambiguity, even spoil any decisionmaking process and result in some overloading amount of information (Kuvaas, 2002). The overloading amount of information may deviate any attention into unessential information (Eppler \& Mengis, 2004) and cause some contradiction among information (Daft \& Lengel, 1993). According to Oreg (2006), a large amount of information is as bad as little amount of information both may cause some resistance to organizational change programs. According to the schematic approach (Fiske \& Tylor, 1984), since an individual has possessed a scheme of organizational changes, it is merely a certain aspect one pays attention to, although a large amount of information exists, but not all are taken (Bartunek \& Moch, 1987). In other words, a large amount of information is not important according to the schematic approach (Bartunek \& Moch, 1987).

It can be concluded that there is an argument whether or not the quantity of information is important among the information-based theory.Because of that teoritical gap, it is sugested to do a research more focused on an information framing wich is how the essentially same information is presented or framed in other fashions (Oreg, 2006; Liu \& Perrewe, 2005). A research on the effects of information framing on attitudes towards an organizational change setting has not much been paid attention (Oreg, 2006), though the concept of information framing might potentially be able to predict perceptions, decision making and individual attitudes (Merilainen \& Vos, 2013; Mandel, 2014). Information framing may allow for the information processing (Hallahan, 1999). Individual tends to use cognitive heuristicor the rule of the thumbwhen encountering any information framing (Kahneman \& Tversky, 1979). The effect of any information framing on attitudes according to Nelson, Oxley, and Clawson (1997) is not towards some changes in the belief in the information substance but the weighing of values to the framed information. If any information framing may result in positive evaluation, positive attitudes will be produced, whereas if the information framing may bear some negative evaluation, negative attitudes will be generated. (Fisbein \& Ajzen, 1975; Ajzen, 1991). Following this line of thought, then it is necesary to use information base theory on attitude towards change study.

Information Factor and Attitudes toward change

In some researches it is found that the information factor may give strong effects on attitudes towards organizational changes programs (Wanberg \& Banas, 2000; Liu \& Perrewe, 2005). According to Wanberg dan Banas (2000), information plays very vital roles in the context of organizational changes. Without information, employees will not know exactly what will happens and it may cause their feelings to be suppressed (Schweiger \& Denisi, 1991). In any situation with no information, employees usually rely on rumors (Napier, Simon, \& Stratton, 1989). Such a condition also makes them look for information out of organization (Richardson \& Denton, 1996). Rumors and information from outer sources may trigger biases in perception, and also cynical attitudes (Reichers, Wanous, \& Austin,1997), and resistance to organizational changes (Stanley, Meyer, \& Topolnytsky, 2005).

The main objective of giving information is that one knows and may anticipate any changes that might happen, any consequences arisen, and any new roles one plays in the process of the change (Dam, Oreg, \& Schyns, 2008). Information may also reduce any uncertainty (Kramer, 1993; Miller \& Monge, 1985; Jimmieeson, Terry, \& Callan, 2004; Dam, Oreg, \& Schyns, 2008) and increase the level of efficacy (Terry \& Jimmieson, 2003) during the process of organizational changes. Information availability is positively correlated with acceptance (Wanberg \& Banas, 2000) and cooperation during the process of the change (Dam, Oreg, \& Schyns, 2008). Even, Miller dan Monge (1985) found that it is better to have little, though negative information than none.

One of the alternative theories that may be used to explain the effect of information on the organizational change programs is the expectancy value model [EVM] of attitude proposed by Fishbein and Ajzen (1975). The EVM considers that any attitude is from belief in the magnitude of either positive or negative value possessed by the object of attitude (Fishben \& Ajzen, 1975). The object of attitude believed has positive consequences, bearing favorable attitudes, negative ones, unfavorable attitudes (Fishben \& Ajzen, 1975). Positive or negative evaluation of an object of 
attitude is based on any information one receives (Ajzen, 1991, 2011; Ajzen \& Fishbein, 2008; Petty \& Wegener, 1998). Information on the value of the object of attitude is a basic factor in the EVM. Information may reinforce or weaken belief, where this then influences one's attitude towards the object of attitude (Nelson, Oxley, \& Clawson, 1997; Chong \& Druckman, 2007).

\section{How do information framing affects attitudes}

Sometimes one wants to do something because of the information framing instead of information substance factors (Chong \& Druckman, 2007; Hallahan, 1999; Merilainen \& Vos, 2013). Though differently framed, the meaning of information remains the same (Merilainen \& Vos, 2013). Interestingly, one may be influenced by information framing. This fact is considered as evidence that there is an irrationality side in human mind when one is making a decision (Mandel, 2014; Schlottmann \& Tring, 2005). There some theories that may be adopted to explain why one is influenced by information framing.

According to the prospect theory (Kahneman \& Tversky, 1979), a positively framed information causes an individual has a tendency to choose an alternative with sure gain than uncertain gamble. This tendency is called as risk aversion. But when an information is negatively framed, most people choose risky gamble than sure loss; it is called as risk seeking (Mandel, 2014; Peng, Miao, Feng, \& Xiao, 2013; Chong \& Druckman, 2007; Pinon \& Gambara, 2005). According to the simple cue effect perspective, information which is positively frame tends to be more quickly reacted to (Smith \& Petty, 1996), much more easily processed in the cognitive domain (Dunegan, 1993), and more persuading to individuals (Petty \& Wegener, 1998). One tends to have some favorable impression to the mead which is positively described ( $75 \%$ fat free) than that negatively described ( $25 \%$ fat) (Levin, 1987). The negativity bias hypothesis perspectivestates that any information which is negatively framed tends to be more strongly reacted to (Dunegan, 1993; Gonzales, Dana, Koshino, \& Just, 2005; Kahneman \& Tversky, 1979), carefully ad seriously processed, and to have very strong effects on attitudes (Smith \& Petty, 1996; Petty \& Wegener, 1998).

The explanations given by the prospect theory, simple cue effect and the negativity bias hypothesis seems incoherent because it is unclear which frame more determines attitudes. It looks that it is necessary to explore other perspectives which are stronger. Some researchers state that the expectancy value model of attitude (EVM) perspective (Ajzen \& Fishbein, 2008) seems to be able to solve the problem. The EVM perspective assumes that information framing works by activating information saved in an individual memory (Nelson, Oxley, \& Clawson, 1997). Information framing does not serve as supplying new information on an issue, but weighing any consideration or consequences related to the issue (Nelson, Oxley, \& Clawson, 1997; Chong \& Druckman, 2007). The weight of an issue may be from anything arousing motivation, attracting attention, becoming one's interests and need (Nelson, Oxley, \& Clawson, 1997). In the EVM perspective, attitude is not merely influenced by the framing valence, but more caused by the magnitude of value of the object of attitude described in the framing (Chong \& Druckman, 2007; Ajzen \& Fishbein, 2008; Ajzen, 1991; Brinol \& Petty, 2012).

On the base of the meta analysis, two framing strategies widely used as communication strategy are found, namely action framing and attribute framing(Pinon \& Gambara, 2005; Merilainen \&Vos, 2013). Action framing strategy is a model of conveying information focused on whether it is important or not to do a certain action with its consequence accompanying the action (Hallahan, 1999). Attribute framing strategy is the model of delivering information on the quality of object, event, or persons under negative or positive perspectives (Hallahan, 1999; Pinon \& Gambara, 2005; Merilainen \& Vos, 2013).

Information arranged using the action framing may be seen in a research by Peng, Li, Miao, Feng dan Xiao (2013, p.163); which is positively arranged :

" Doctor tells you that although you particularly like to eat bacon, if you stop eating, your body cholesterol content would be significantly reduced, and thus the posibility of suffering from cardiovascular disease would be greatly reduced. Would you continue to eat bacon?",

and negatively arranged:

"Doctor tells you that although you particularly like to eat bacon, if you continue to eat, your body cholesterol content will significantly rise, and thus the posibility of suffering from cardiovascular disease would be greatly increased. Would you continue to eat bacon?"

Research results indicate that subjects with positive action framing strategy shows higher willingness to obey doctors' advices than those with negative framing strategy (Peng, Li, Miao, Feng, \& Xiao, 2013). Based on the EVM perspective, less risky situation or the cholesterol content reduction and heart diseases avoidance are considered to be more beneficial than higher risks in diseases. On the basis of theorical studies and research results on the relations between positive (negative) action framing and attitude, the following hypotheses are proposed:

Hypothesis 1a: Positive action framing positivellyaffects attitudes towards change.

Hypothesis 1b: Negative action framing negativellyaffects attitudes towards change.

Peng, Li, Miao, Feng dan Xiao (2013, p.163) arrange information positively in the attribute framing ("100 patients taking one kind of medicine, 70 patients became better. How would you evaluate the drug effect?") and also negatively ("100 patients taking one kind of medicine, 30 patients didn't become better. How would you evaluate the drug effect?"). Both attribute framings are presented to two different groups. The result is that the subjects receiving positive 
attribute framing tend to make more positive evaluation than those receiving negative attribute framing (Peng, Li, Miao, Feng, \& Xiao, 2013). Based on that explanation the following hypotheses are proposed:

Hypothesis 2a: Positive attribute framing positivellyaffects attitudes towards change

Hypothesis 2b: Negative attribute framing negativellyaffects attitudes towards change.

\section{CONCLUSION}

It can be concluded that social influence and individual difference-based theory has been able to explain the antecedent of attitudes well. But the information-based theory still leaves some problems, especially there is an argument whether the quantity of information is important for the uncertainty reduction theory and the information processing approach on the one hand, and for behavioral decision making approach dan the schematic approachon the other hand. To solve such a theoretical gap between the information-based theory group, author suggests that it is necessary to do a research more focused on an information framing; how the essentially same information is presented or framed in other fashions. The rationale is that any attitudes towards organizational changes may not be influenced by the amount or content of information but by how the information is framed.

\section{REFERENCES}

Ajzen, I. (1991). The theory of planned behavior Organizational Behavior and Human Decision Processes. 50: 179-211.

Ajzen, I. (2011). Job satisfaction, effort, and performance: A reasoned action perspective. Contemporary Economics. 1(4), 32-43.

Ajzen, I., \& Fishbein, M. (2008). Scaling and testing multiplicative combinations in the expectancyvalue model of attitude. Journal of Applied Social Psychology. 38(9), 2222-2247.

Bandura, A. (1977). Self-efficacy: toward a unifying theory of behavioural change. Psychological Review. 84(2), 191-215.

Bartunek, J.M., \& Moch, M.K. (1987). First-order, secondorder, and third-order change and organizational devolepment interventions: A cognitive approach. Journal of Applied Behavioral Science. 23, 483-500.

Berger, C.R., \& Calabrese, R.J. (1975). Some exploration in initial interaction and beyond: Toward a developmental theory of communication. Human Comunication Research. 1, 99-112.

Bizer, G. Y., Larsen, J. T., \& Petty, R. E. (2011). Exploring the valence-framing effect: Negative framing enhances attitude strength. Political Psychology. 32(1), 59-80

Brinol, P., \& Petty, R. E. (2012). A history of attitudes and persuasion research. In A. Kruglanski \& W. Stroebe (Eds.), Handbook of the history of social psychology. 285-320. New York: Psychology Press.

Chang, Meng-Chen, \& Wu, Chao-Chan. (2015). The effect of message framing on pro-environmental behavior intentions. British Food Journal. 117(1), 339357.

Cropanzano, R. \& Mitchel, M. S. (2005). Social exchange theory: An interdisciplinary review. Journal of Management. 31(6), 874-900.

Chong, D. \& Druckman, J. N. (2007). Framing theory. Annu.Rev.Polit.Sci. 10, 103-126.

Daft, R., \& Lengel, R.H. (1986). Organizational information requirements, media richness and structural design. Management Science, 32(5), 554-571.

Dam, K. Van., Oreg, S., \& Schyns, B. (2008). Daily work contexts and resistance to organizational change: The role of leader-member exchange, development climate, and change process characteristics. Applied Psychology: An International Review. 57(2), 313-334.

Danisman, A. (2010). Good intentions and failed implementations: Understanding culture-based resistance to organizational change. European Journal of Work and Organizational Psychology. 19(2), 200-220.

Dunegan, K.J. (1993). Framing, cognitive modes and image theory: Toward an understanding of a glass half full. Journal of Applied Psychology. 78(3), 491503.

Ellis, B.H. (1992). The effects of uncertainty and source credibility on attitudes about organizational change. Management Communication Quarterly. 6(1), 34-57.

Emerson, R. M. (1976). Social Exchange Theory. Annual Review of Sociology. 2, 335-362.

Eppler, M.J., \& Mengis, J. (2004). The concept of information overload: A review of literature from organization science, accounnting, marketing, MIX and related disciplines. The Information Society. 20, 325-344.

Fishbein, M., \& Ajzen, I. (1975). Belief, attitude, intention and behavior: An itroduction to theory and research. Philippines: Addison-Wesley Publishing Company, Inc.

Fiske, S.T., \& Taylor, S.E. (1984). Social Cognition Reading, MA: Addison-Wesley.

Fugate, M., Prussia, G.E., \& Kinicki, A.J. (2012). Managing employee withdrawal during organizational change: The role of threat appraisal. Journal of Management. 38(3), 890-914.

Gonzales, C., Dana, J., Koshino, H., \& Just, M. (2005). The framing effect and risky decisions: Examining cognitive functions with fMRI. Journal of Economic Psychology. 26, 1-20.

Hallahan, K. (1999). Seven models of framing: Implications for public relations. Journal of Public relations Research. 11(3), 205-242.

Heilman, R. M., \& Miclea, M. (2016). Risk seeking preferences: An investigation of framing effects acrosss decisional domains. Cognition, Brain, Behavior. An Interdisciplinary Journal. 20(1), 117.

Herold, D.M., Fedor, D.B., \& Caldwell, S.D. (2007). Beyond change management: A multilevel investigation of contextual and personal influences on employees' commitment to change. Journal of Applied Psychology. 92(4), 942-951.

Herzig, S.E., \& Jimmieson, N. L. (2006). Middle managers' uncertainty management during organizational change. Leadership \& Organization Development Journal. 27(8), 628-645. 
Hodgkinson, G. P., \& Healey, M. P. (2008). Cognition in organizations. Annual Review of Psychology. 59, 387-417.

Hornung, S., \& Rousseau, D.M. (2007). Active on the job proactive in change, how autonomy at work contributes to employee support for organizational change. The Journal of Applied Behavioral Science. 43(4), 401-426.

Huangfu, G., \& Zhu, L. (2014). A reexamination of the robustness of the framing effect in cognitive processing. Social Behavior and Personality. $42(1), 37-44$.

Irvin, J. E. (2003). Contruction of smoking-relevant risk perceptions among college students: The influence of need for cognition and message content. Graduate School Theses and Dissertations. University of South Florida.

Jimmieson, N.L., Terry, D.J., \& Callan, V.J. (2004). A longitudinal study of employee adaptation to organizational change: The role of changerelated information and change-related selfefficacy. Journal of Occupational Health Psychology. 9(1), 11-27.

Jones, R. A., Jimmieson, N. L., \& Griffiths, A. (2005). The impact of organizational culture and reshaping capabilities on change implementation success: The mediating role of readiness for change, Journal of Management Studies. 42, 361-386.

Kahneman, D., \& Tversky, A. (1979). Prospect theory: An analysis of decision under risk. Econometrica. 47, 263-291.

Kao, D.T. (2011). Message sidedness in advertising: The moderating roles of need for cognition and time presure in persuasion. Scandinavian Journal of Psychology. 52, 329-340.

Knippenberg, B., Martin., \& Tyler, T. (2006). Processorientation versus outcom-orientation during organizational change: The role of organizational identification. Journal of Organizational Behavior. 27, 685-704.

Kramer, M.W. (1993). Communication and uncertainty reduction during job transfers: Leaving and joining processes. Communication Monographs. 60, 179-199.

Kuntz, J.R.C., \& Gomes, J.F.S. (2012). Transformational change in organizations: a self-regulation approach. Journal of Organizational Change Management. 25(1), 143-162.

Kuvaas, B. (2002). An exploration of two competing perspectives on informational contexts in top management strategic issue interpretation. The Journal of Management Studies, 39(7), 9771001.

Lin, Hsin-Hui, \& Yang, Shu-Fei. (2014). An eye movement study of attribute framing in online shopping. Journal of Marketing Analytics. 2(2), 72-80.

Lines, R. (2005). The Structure and function of attitudes toward organizational change. Human Resource Development Review. 4(1), 8-32.

Levin, I. P. (1987). Associative effects of information framing. Bulletin of the Psychometric Society. 25(2), 85-86.

Liu, Y., \& Perrewe, P.L. (2005). Another look at the role of emotion in organizational change: A process model. Human Reseource Management Review. $15,263-280$.

Mandel, D. R. (2014). Do framing effects reveal irrational choice? Journal of Experimental Psychology: General. 143(3), 1185-1198.

Merilainen, N., \& Vos, M. (2013). Framing issues in the public debate: The case of human rights.
Corporate Communications: An International Journal. 18(1), 119-134.

Miller, K., \& Monge, P. (1985). Social information and employee anxiety about organizational change. Human Communication Research. 11, 365-385.

Napier, N.K., Simon, G., \& Stratton, K. (1989). Communication during a merger: Experience of two banks. Human Resource Planning. 12(2), 105-122.

Neiva, R.R., Ros, M., Torres da Paz, M.D.G. (2005). Attitude towards organizational change: validation of scale. Psychology in Spain. 9(1), 81-90.

Nelson, T. E., Oxley, Z. M. \& Clawson, R. A. (1997). Toward a psychology of framing effects. Political Behavior. 19(3), 221-246.

Oreg, S. (2003). Resistance to change: Developing an individual differences measure. Journal of Applied Psychology. 88(4), 680-693.

Oreg, S. (2006). Personality, context, and resistance to organizational change. European Journal of Work and Organizational psychology. 15(1), 73101.

Oreg, S., Vakola, M., \& Armenakis, A. (2011). Change recipients' reaction to organizational change: a 60 -year review of quantitative studies. The Journal of Applied Behavioral Science. 47(4), 461-524.

Peng, J., Li, H., Miao, D., Feng, X., \& Xiao, W. (2013). Five different types of framing effects in medical situation: A preliminary exploration. Iranian Red Crescent Medical Journal. 15(2), 161-165.

Petty, R. E., \& Wegener, D. T. (1998). Attitude change: Multiple roles for persuasion variables. In D. Gilbert, S. T. Fiske, \& G. Lindzey (Eds.), Handbook of social psychology (4th cd.,323390). New York: McGraw-Hill.

Pinon, A., \& Gambara, H. (2005). A meta-analytic review of framming effect: Risky, atribute and goal framing. Psicothema. 17(2), 325-331.

Reichers, A.E., , J.T. (1997). Understanding and managing cynicism about organizational change. Academy of Management Executive. 11, 48-59.

Richardson, R., \& Denton, D.K. (1996). Communicating change. Human Resource Management. 35(2), 203-216.

Roccas, S., Sagiv, L., Schwartz, S. H., \& Knafo, A. (2002). The Big Five personality factors and personal values. Personality and Social Psychology Bulletin. 28, 789-801.

Salancik, G.R., \& Pfeffer, J. (1978). A social information processing approach to job attitudes and task design. Administrative Science Quarterly. 23(2),224-253.

Schwartz, S. (1992). Universals in the content and structure of values: Theoretical advances and empirical tests in 20 countries. In M. P. Zanna (Ed.), Advances in Experimental Social Psychology. 25, 1-65. San Diego: Academic Press.

Schweiger, D.M., \& Denisi, A.S. (1991). Communication with employees following a merger: A longitudinal field experiment. Academy of Management Journal. 34(1), 110-135.

Schlottmann, A., \& Tring, J. (2005). How children reason about gains and losses: Framing effects in judgement and choice. Swiss Journal of Psychology. 63(3), 153-171.

Smith, S. M., \& Petty, R. E. (1996). Message framing and persuasion: A message processing analysis. Personality and Social Psychology Bulletin. 22, 257-268. 
Stanley, D.J., Meyer, J.P., \& Topolnytsky. L. (2005). Employee cynicism and resistance to organizational change. Journal of Business and Psychology. 19(4), 429-459.

Sverdlik, N., \& Oreg, S. (2009). Personal values and conflicting motivational forces in the context of imposed change. Journal of Personality. 77(5), $1437-1465$.

Shin, S. (2013). Understanding organizational change into entrepreneurship: A theoretical frameworks and integration. Management Review: An International Journal. 8(2), 29-53.

Terry, D.J. \& Jimmieson, N.L. (2003). A stress and coping approach to organizational change: Evidence from three field studies. Australian Psychologist. $38,92-101$

Tsaousis, I. (1999). The traits personality questionaire (TPQue): a Greek measure for the five factor model. Personality and Individual Differences. 26, 271-283.

Wagner, B.C., \& Petty, R.E. (2011). The elaboration likelihood model of persuasion: Thoughtful and non-thoughtful social influence. In Derek Chadee (Eds.), Theories in Social Psychology (96-116). Blackwell Publishing Ltd.

Wanberg, C.R., \& Banas, J.T. (2000). Predictors and outcomes of openness to changes in a reorganizing workplace. Journal of Applied Psychology. 85(1), 132-142.

Wharton, R.F., \& Brunetto, Y. (2007). Organizational relationship quality and service employee acceptance of change in SMEs: A social exchange perspective. Journal of Management \& Organization. 13(2), 114-125. 